\title{
Smoking decreases the level of circulating CD34+ progenitor cells in young healthy women - a pilot study
}

\author{
Antje Ludwig ${ }^{+1}$, Nicoline Jochmann+11, Andras Kertesz ${ }^{1}$, Claudia Kuhn' ${ }^{1}$, Simone Mueller ${ }^{1}$, Christine Gericke2, \\ Gert Baumann ${ }^{1}$, Karl Stangl ${ }^{1}$ and Verena Stangl ${ }^{* 1}$
}

\begin{abstract}
Background: Decreased levels of circulating bone marrow-derived progenitor cells have been associated with risk factors and cardiovascular diseases. Smoking is the most important modifiable risk factor for atherosclerosis in young women. The aim of this pilot study was to assess in healthy premenopausal women without other risk factors for cardiovascular disease the influence of nicotine abuse on the number of circulating progenitor cells in relation to endothelial function.
\end{abstract}

Methods: The number of endothelial progenitor cells, measured as colony-forming units in a cell-culture assay (EPCCFU) and the number of circulating CD34 + and CD34 + /CD133 + cells, measured by flow cytometry, was estimated in 32 women at the menstrual phase of the menstrual cycle. In addition, flow-mediated dilation (FMD) was assessed as a marker for vascular function. In a subgroup of these women $(n=20)$, progenitor cells were also investigated at the midfollicular and luteal phases of the menstrual cycle.

Results: Compared to non-smokers, the abundance of circulating CD34 + cells was significantly lower in smoking women in the menstrual, mid-luteal, and mid-follicular phases of the menstrual cycle. The number of CD34 + progenitor cells was revealed to have significant positive correlation with FMD in young healthy women, whereas CD34 + /CD133 + progenitor cells and EPC-CFU showed no significant correlation.

Conclusion: The number of CD34 + progenitor cells positively correlates with FMD in young healthy women and is decreased by smoking.

\section{Background}

Vascular homeostasis is controlled not solely by cells of the vessel wall, but also by circulating bone marrowderived progenitor cells (PCs). In particular, a subset of circulating stem cells, designated endothelial progenitor cells (EPCs), is considered to contribute to endothelial cell regeneration and neovascularisation [1]. Levels of circulating PCs/EPCs have been correlated with endothelial function, atherogenic risk factors, as well as various cardiovascular diseases [2-5]. Although prospective data are still lacking, the number of PCs/EPCs is evidently inversely related to cardiovascular risk [6,7].

\footnotetext{
* Correspondence: verena.stangl@charite.de

1 Med. Klinik mit Schwerpunkt Kardiologie und Angiologie, Charité -

Universitaetsmedizin Berlin, Campus Mitte, Berlin, Germany + Contributed equally

Full list of author information is available at the end of the article
}

Since a clear and generally accepted definition of EPCs has until now not been established, most studies investigating the nature and function of EPCs have focused on flow-cytometric analysis of circulating cells that are positive for the haematopoietic stem cell markers CD34, CD133 and for the vascular endothelial growth factor receptor 2 (VEGFR2), and/or have concentrated on analysis of in vitro formation of colony-forming units (EPCCFU) $[1,6]$. There is some evidence that levels of circulating progenitor cells positive for CD34 (CD34 + cells) are more strongly correlated with cardiovascular risk factors than are progenitor cell populations with various combinations of CD34, CD133, and VEGFR2 [6].

Women of reproductive age are exposed to lower cardiovascular risk than are age-matched men [8]. This is generally attributed to differences in sex hormones and, 
specifically, to the protective cardiovascular properties of female estrogens [9,10]. Notably, elevated estrogen plasma concentrations in women correlate with higher levels of circulating EPCs [11]. They accordingly promote vascular repair and inhibit neointima formation after carotid artery injury in mice [11]. The effects of estrogens on EPCs are mediated by nitric oxide and antiapoptotic mechanisms [11,12]. Changes in hormonal levels during the menstrual cycle are likewise reflected in the number of circulating progenitor cells. The highest levels of progenitor cells positive for CD34 and CD133 (CD34 + I $\mathrm{CD} 133+)$ were measured following the pre-ovulatory phase: i.e., the cycle phase with the highest levels of estrogens [13-15].

Smoking is the most important modifiable risk factor for atherosclerosis in young women [16]. The biological mechanisms linking smoking and atherogenesis are complex and not fully understood. In addition to inflammation, potential mechanisms by which smoking increases the risk of cardiovascular diseases include systemic haemostatic and coagulatory disturbances, lipid abnormalities, increase in oxidative stress, and vascular endothelial dysfunction [17-19]. It has been shown that smoking attenuates the number of progenitor cells in the circulatory system of male individuals, and that smoking cessation leads to a rapid elevation in progenitor cell levels [20]. It is presently unknown whether there is a link between smoking and the amount of progenitor cells in women in which endogenously released estrogens may further influence progenitor cell levels.

The aim of the present study was accordingly to investigate whether smoking influences the number of progenitor cells in young healthy women without other cardiovascular risk factors, and whether there is correlation between the amount of progenitor cells and endothelial function assessed as flow-mediated dilation (FMD) of the brachial artery.

\section{Methods}

\section{Study population}

Non-smoking and smoking women aged 25 to 35 years were recruited by press advertisements. Subjects with chronic diseases or known cardiovascular risk factors other than smoking were excluded. All women had regular menstrual cycles and had not taken medication for more than 3 months before study entry. The admitted non-smoking women had never smoked, and smoking women were required to have smoked at least 15 cigarettes/day for at least one year. Women were invited for preliminary examinations during the luteal phase at day M-7 of the previous menstrual cycle (day 1 is the first day of menstrual bleeding $[\mathrm{M}]$ of the expected following menstrual period). All values for clinical parameters were required to lie within the normal range to allow study inclusion: lipid profile including lipoprotein (a), blood pressure, body mass index, as well as routine internal and endocrine parameters. Serum progesterone was required to be $>18 \mathrm{nmol} / \mathrm{L}$ as a marker of an ovulatory menstrual cycle. The study protocol was approved by the Human Research Committee of the institution and conforms to the principles outlined in the Declaration of Helsinki. All subjects gave written informed consent.

\section{Study design}

All volunteers underwent a clinical examination at the menstrual phase of the menstrual cycle $(M+3$; day 3 after first day of menstrual bleeding). Blood from the antecubital vein was collected at 8.00 a.m. after a 12-hour overnight fast. The samples were centrifuged and stored at $-70{ }^{\circ} \mathrm{C}$ until chemical analysis. For analysis of progenitor cells, blood was collected in EDTA vials and processed immediately. Endothelial function was measured by high-resolution vascular ultrasound. To assess the relevance of cyclical hormonal changes on progenitor cells, levels of these cells were additionally investigated in a subgroup of women at mid-follicular $(M+7$; day 7 after first day of menstrual bleeding) and at mid-luteal (M-7) phases of the menstrual cycle. In this subgroup at M-7, the required minimum limit for progesterone was 18 $\mathrm{nmol} / \mathrm{L}$; otherwise the data were excluded from the analyses.

\section{EPC culture assay}

Peripheral blood monocytic cells (PBMCs) were isolated from $18 \mathrm{ml}$ of whole blood by density-gradient centrifugation with Ficoll-Paque ${ }^{\mathrm{mm}}$ (Amersham Pharmacia). Cells were plated in M199 medium (GIBCO 31153) with supplements $(100 \mathrm{U} / \mathrm{L}$ penicillin, $100 \mu \mathrm{g} / \mathrm{ml}$ streptomycin, $20 \%$ fetal calf serum) on fibronectin-coated 24-well plates with a density of $1-10^{6}$ cells per well. Nonadherent cells were removed after 3 days of culture, and colony forming units (CFU) were counted under light microscope on day 7 (6 wells per measuring point). Confirmation of endothelial like cell type was performed using the uptake of DiI-acetylated low density lipoprotein (acLDL-DiI) as indicator. Selected samples were positively tested for the expression of CD31 and endothelial nitric oxide synthase and for the formation of three dimensional tube structures in matrigel. Numbers of EPC were calculated as "EPC-CFU per $1 \times 10^{6}$ PBMCs".

\section{Flow cytometry}

Whole blood $(0.5 \mathrm{ml})$ was stained with conjugated antibodies anti-CD34-APC (BD Pharmingen) and antiCD133-PE (Miltenyi). Erythrocytes were subsequently lysed with EasyLyse Solution (Dako). Then the samples were washed with buffer containing phosphate-buffered saline and $0.5 \%$ bovine albumin. The numbers of circulat- 
ing progenitor cells $(\mathrm{CD} 34+$ and $\mathrm{CD} 34+/ \mathrm{CD} 133+)$ were evaluated by flow cytometry (CyAn-ADP, BeckmanCoulter) as follows: The mononuclear cell fraction was identified by their low side scatter. Cells positive for CD34 were gated and examined for additional expression of CD133 (Figure 1A). Fluorescence-labeled, isotypematched nonspecific immunoglobulin G antibodies served as controls for nonspecific staining. All instrument settings and the measurement procedure were stored in a protocol file and remained unchanged throughout the analyses. The gate on the mononuclear cell populations was set individually for each sample, and $5 \times 10^{5}$ PBMCs were measured. The concentrations of progenitor cells were calculated as "progenitor cells \% PBMCs".

\section{Measurement of FMD and NMD}

Endothelial function was measured by high-resolution vascular ultrasound with a $13-\mathrm{MHz}$ linear array transducer (Sonoline Antares, Siemens), as recently described [21]. Briefly, endothelium-dependent FMD was assessed by measuring the change in brachial artery diameter after reactive hyperaemia for 2 minutes, according to estab- lished guidelines [22,23]. Endothelium-independent nitro-mediated dilation (NMD) was measured after sublingual application of nitro-glycerine spray $(0.4 \mathrm{mg})$ for 6 minutes. FMD and NMD were defined as the maximum change in brachial artery diameter, in percent, compared to baseline measurement. Analyses of diameter changes were conducted offline (Tom Tec Imaging Systems) by two blinded investigators.

\section{Statistics}

Values in tables and text are presented as mean \pm standard deviation, and in the figures as mean \pm SEM. All statistical tests were two-sided (level of significance $=0.05$ ). Values with normal distribution were analysed by parametric tests. For comparisons of clinical parameters, which are not normally distributed, nonparametric ranksum tests were used (paired Wilcoxon test, Mann-Whitney test). Correlations are given by the Spearman rank correlation coefficient. A linear regression analysis was performed to test the effect of adjusted age and smoking status on progenitor cells. The statistical model used for evaluation of the variables CD34 +, CD34 + /CD133 + and EPC-CFU over time (menstrual cycle) was a linear

A
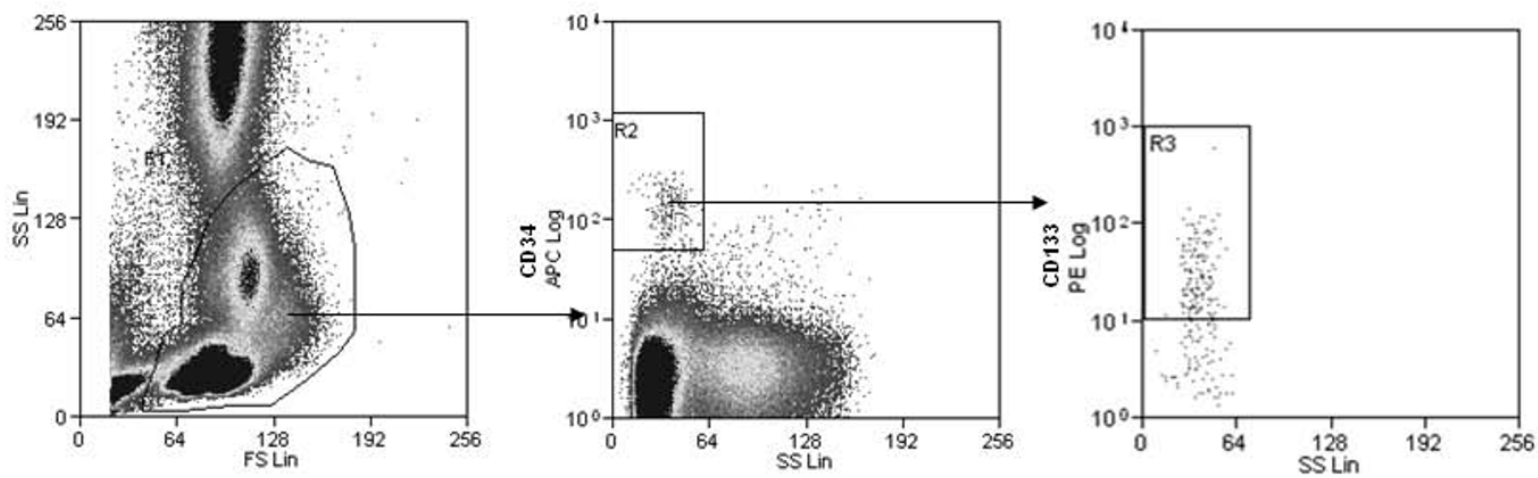

B
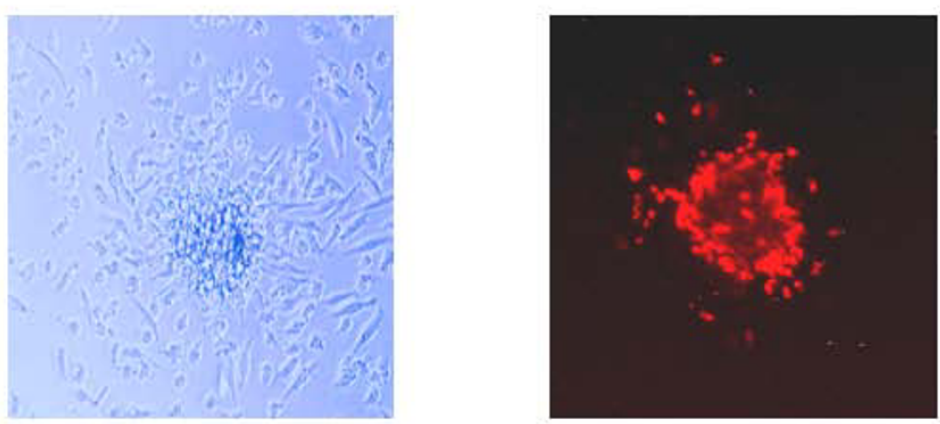

Figure 1 Enumeration of circulating progenitor cells. A) Detection of CD34 + side scatterlow and CD34 + /CD133 + side scatterlow cells, defining circulating progenitor cells, by flow cytometry. B) Endothelial progenitor cells analyzed by in vitro formation of colony forming unit (EPC-CFU) in a cell culture assay of peripheral blood mononuclear cells of young healthy women. Phase contrast photomicrograph of endothelial progenitor cell colony (EPC-CFU) with a central cluster of cells surrounded by migratory spindle shaped cells (left) and fluorescence photomicrograph after staining with acLDL-Dil (right). 
mixed model with fixed and random effects. The analyses were performed with Software SPSS version 16.0 and R version 2.6.2.

\section{Results}

\section{Baseline characteristics}

As described in Table 1, the study population consisted of 32 healthy women (mean age $31.3 \pm 3.2$ years) without overweight, hypertension, dyslipidemia including lipoprotein (a) diabetes, hyperhomocysteinemia, or family history of cardiovascular diseases. Nicotine abuse was the only cardiovascular risk factor established for 17 women within the study population. Smoking women were slightly older $(32.4 \pm 2.9$ vs. $29.7 \pm 2.9$ years, $\mathrm{p}<0.05)$. No other parameters showed significant differences between the two groups. Menstrual cycle was of normal length (mean cycle length $28.7 \pm 2.1$ days). Women of the subgroup that was additionally investigated at mid-follicular and luteal phases of the menstrual cycle $(n=20)$ showed the typical cyclical pattern in the concentrations of sexual steroids.
Effect of smoking on the number of circulating progenitor cells in young healthy women

At menstrual phase $(\mathrm{M}+3$; day 3 after first day of menstrual bleeding) in the 17 smoking women, we found an abundance of CD34 + cells that was significantly lower than among the 15 non-smoking women $(0.06 \pm 0.02$ vs. $0.10 \pm 0.03 \%$ of PMBC, $\mathrm{p}=0.01)$. The CD34 + /CD133 + progenitor cell number was also lower in smoking women, close to significance $(\mathrm{p}=0.056)$. The numbers are in the expected range when compared to studies using similar evaluation methods $[24,25]$.

The mean value of EPC-CFU was clearly lower for smoking than for non-smoking women $(18.8 \pm 18.6$ vs. $36.5 \pm 34.0$ per $10^{6} \mathrm{PBMC}$ ). However, due to extensive variations within the groups, the difference is not statistically significant (Figure 2). In a similar manner, FMD was slightly but not significantly reduced in smoking women. NMD did not show significant differences in the two groups. All results are presented in detail in Table 2.

We next analyzed the number of progenitor cells in the subgroup of women investigated at luteal and follicular

Table 1: Baseline characteristics of the study group $(n=32)$

\begin{tabular}{|c|c|c|c|c|}
\hline & & $\begin{array}{l}\text { Whole group } \\
(n=32)\end{array}$ & $\begin{array}{l}\text { Non-smokers } \\
(n=15)\end{array}$ & $\begin{array}{l}\text { Smokers } \\
(n=17)\end{array}$ \\
\hline Age $^{*}$ & (years) & $31.3 \pm 3.2$ & $29.7 \pm 2.9$ & $32.4 \pm 2.9$ \\
\hline BMI & $\left(\mathrm{kg} / \mathrm{m}^{2}\right)$ & $21.3 \pm 1.5$ & $21.3 \pm 1.7$ & $21.3 \pm 1.4$ \\
\hline Cycle length & (days) & $28.7 \pm 2.1$ & $29 \pm 2.2$ & $28.5 \pm 1.5$ \\
\hline Nicotine abuse & (pack years) & - & - & $14.8 \pm 4.6$ \\
\hline RR syst & $(\mathrm{mmHg})$ & $98 \pm 33$ & $102 \pm 30$ & $94 \pm 36$ \\
\hline RR diast & $(\mathrm{mmHg})$ & $65 \pm 22$ & $67 \pm 20$ & $63 \pm 25$ \\
\hline Total cholesterol & (mg/dl) & $164 \pm 23$ & $158 \pm 17$ & $168 \pm 27$ \\
\hline $\mathrm{HDL}$ & $(\mathrm{mg} / \mathrm{dl})$ & $64.4 \pm 10.1$ & $66.9 \pm 9.1$ & $62.2 \pm 10.7$ \\
\hline LDL & $(\mathrm{mg} / \mathrm{dl})$ & $85.8 \pm 24.5$ & $79.9 \pm 16.5$ & $91.1 \pm 29.4$ \\
\hline Triglyceride & $(\mathrm{mg} / \mathrm{dl})$ & $67.7 \pm 28.4$ & $57.5 \pm 13.4$ & $76.7 \pm 35.0$ \\
\hline Lipoprotein(a) & $(\mathrm{mg} / \mathrm{dl})$ & $7.0 \pm 4.0$ & $7.4 \pm 4.2$ & $6.6 \pm 3.8$ \\
\hline hsCrP & (mg/dl) & $0.08 \pm 0.07$ & $0.09 \pm 0.08$ & $0.08 \pm 0.06$ \\
\hline Insulin & $(\mathrm{mlU} / \mathrm{l})$ & $5.6 \pm 2.2$ & $5.2 \pm 2.1$ & $6.0 \pm 2.3$ \\
\hline Glucose & $(\mathrm{mg} / \mathrm{dl})$ & $87.7 \pm 7.2$ & $87.0 \pm 4.9$ & $88.4 \pm 8.8$ \\
\hline Homocystein & $(\mu \mathrm{mol} / \mathrm{l})$ & $8.5 \pm 1.7$ & $8.2 \pm 1.7$ & $8.7 \pm 1.8$ \\
\hline Folic acid & $(\mu \mathrm{g} / \mathrm{l})$ & $8.8 \pm 4.5$ & $10.2 \pm 5.6$ & $7.6 \pm 2.8$ \\
\hline Uric acid & $(\mu \mathrm{mol} / \mathrm{l})$ & $3.9 \pm 0.9$ & $3.7 \pm 0.9$ & $4.1 \pm 0.8$ \\
\hline Estradiol & (pmol/l) & $613 \pm 194$ & $598 \pm 191$ & $626 \pm 201$ \\
\hline Progesterone & $(\mathrm{nmol} / \mathrm{l})$ & $51.4 \pm 17.6$ & $51.2 \pm 16.4$ & $51.5 \pm 19.2$ \\
\hline $\mathrm{LH}$ & (IU/I) & $4.7 \pm 2.9$ & $4.5 \pm 3.8$ & $4.9 \pm 2.0$ \\
\hline FSH & $(\mathrm{IU} / \mathrm{I})$ & $2.7 \pm 1.2$ & $2.8 \pm 1.5$ & $2.7 \pm 0.7$ \\
\hline
\end{tabular}

${ }^{*} \mathrm{p}<0.05$ for comparison of non-smokers with smokers; values are mean $\pm \mathrm{SD}$;

$\mathrm{BMI}=$ body mass index; $\mathrm{LH}=$ luteinising hormone; FSH = follicle stimulating hormone; RR syst = systolic blood pressure; RR diast = diastolic blood pressure; $\mathrm{HDL}=$ high-density lipoprotein; $\mathrm{LDL}=$ low-density lipoprotein; $\mathrm{hsCrP}=$ high-sensitivity $\mathrm{C}$-reactive protein. 

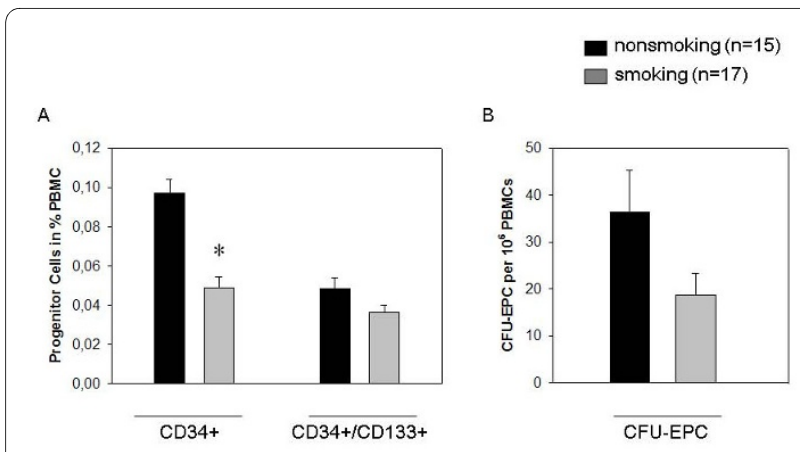

Figure 2 Influence of smoking on the number of circulating progenitor cells. A) CD34 + and CD34 + /CD133 + cell populations in peripheral blood measured by flow cytometry. Level of circulating CD34 + progenitor cells is significantly decreased by smoking in young healthy women. B) Endothelial progenitor cells analyzed by in vitro formation of colony forming unit (EPC-CFU) in a cell culture assay of peripheral blood mononuclear cells. Number of EPC-CFU is decreased by smoking in young healthy women. ${ }^{*} p<0.05$ for comparison of nonsmokers with smokers; values are mean \pm SEM

phases of the menstrual cycle. Results are summarized in Table 3. Only women with an ovulatory menstrual cycle were included in this subgroup $(n=20)$. Concentration of sexual steroids showed the typical cyclical pattern, with significantly higher levels of estradiol and progesterone at mid-luteal phase than in the menstrual and mid-follicular phases (8 non-smoking women, 12 smoking women). Neither the number of CD34 + and CD34 + /CD133 + progenitor cells nor the number of EPC-CFU showed significant differences between the three investigated time points of the menstrual cycle. However, in correlation with results found at the menstrual phase, CD34 + cell levels were significantly lower in smoking than in nonsmoking women at mid-follicular and mid-luteal phases. The numbers of EPC-CFU showed a non-significant trend towards lower values in smoking women, whereas
CD34 + /CD133 + progenitor cell counts were not influenced by smoking in this subgroup (Table 3 ).

\section{Number of circulating CD34 + cells in young healthy women correlates with endothelial function}

We examined women at menstruation, the cycle phase with lowest concentrations of sexual steroids. Levels of EPC-CFU showed broad interindividual distribution $(0.7$ to 118.3 cells per $10^{6}$ per PBMCs). Levels of circulating progenitor cells estimated by flow cytometry ranged from $0.03 \%$ to $0.145 \%$ and $0.02 \%$ to $0.10 \%$ of PBMCs for CD34 + and CD34 + /CD133 + progenitor cells, respectively. The number of CD34 + progenitor cells revealed a significant positive correlation with FMD $(r=0.435, \mathrm{p}=0.014)$ (Figure 3). Levels of CD34 + /CD133 + progenitor cells and of EPC-CFU, however, showed no correlation with FMD. NMD likewise failed to correlate with the number of CD34 + cells, CD34 + /CD133 + cells, or EPC-CFU. Adjustment of FMD, number of CD $34+$ cells, and number of CD34 + /CD133 + cells for age did not disclose an influence of this variable.

\section{Discussion}

The major observation of the present study is that levels of circulating progenitor cells and endothelial progenitor cells are decreased in healthy young women with chronic nicotine abuse. In addition, the number of CD34 + progenitor cells positively correlates with endothelial function assessed as flow-mediated dilation of the brachial artery.

Previous studies have shown that chronic nicotine abuse leads to a decrease in circulating progenitor cell levels in men [20]. Two hypotheses have been discussed to explain underlying mechanisms: First, smoking-related ROS production may decrease the bioavailability of nitric oxide (NO), thereby reducing mobilization of PCs from the bone marrow [26,27]. Second, smoking leads to endothelial dysfunction, and injured vessels may use PCs

Table 2: Summary of results for $M+3$

\begin{tabular}{|c|c|c|c|c|}
\hline & & $\begin{array}{l}\text { Whole group } \\
(n=32)\end{array}$ & $\begin{array}{l}\text { Non-smokers } \\
(n=15)\end{array}$ & $\begin{array}{l}\text { Smokers } \\
(n=17)\end{array}$ \\
\hline CD34+ & (\% of PMBC) & $0.08 \pm 0.03$ & $0.10 \pm 0.03$ & $0.06 \pm 0.02^{*}$ \\
\hline CD34+/CD133+ & (\% of $\mathrm{PMBC}$ ) & $0.04 \pm 0.02$ & $0.05 \pm 0.02$ & $0.04 \pm 0.01$ \\
\hline EPC-CFU & (per 106 PBMC) & $27.1 \pm 28.0$ & $36.5 \pm 34.0$ & $18.8 \pm 18.6$ \\
\hline FMD & $(\%)$ & $9.2 \pm 4.1$ & $9.9 \pm 4.5 \%$ & $8.5 \pm 3.7$ \\
\hline NMD & $(\%)$ & $25.0 \pm 7.3$ & $24.3 \pm 7.2$ & $25.7 \pm 7.5$ \\
\hline Estradiol & $(\mathrm{pmol} / \mathrm{l})$ & $151 \pm 75$ & $175 \pm 76$ & $130 \pm 70$ \\
\hline Progesterone & $(\mathrm{nmol} / \mathrm{l})$ & $3.86 \pm 1.54$ & $3.12 \pm 1.29$ & $4.5 \pm 1.48$ \\
\hline
\end{tabular}

${ }^{*} \mathrm{p}<0.05$ for comparison of non-smokers with smokers; values are mean \pm SD; CD34+= progenitor cells positive for haematopoietic stem cell marker CD34; CD34+/CD133+ = progenitor cells positive for hematopoietic stem cell markers CD34 and CD133; EPC-CFU = endothelial progenitor cells analyzed by in vitro formation of colony forming unit; FMD = flow-mediated dilation; NMD = nitro-mediated dilation 
Table 3: Levels of progenitor cells during the menstrual cycle

\begin{tabular}{|c|c|c|c|c|c|c|c|}
\hline & & & $\begin{array}{c}\text { non-smokers } \\
(n=8)\end{array}$ & & & $\begin{array}{c}\text { Smokers } \\
(n=12)\end{array}$ & \\
\hline & & $M+3$ & $M+7$ & $M-7$ & $M+3$ & $M+7$ & $M-7$ \\
\hline CD34+ & (\%PMBC) & $0.08 \pm 0.03$ & $0.09 \pm 0.03$ & $0.08 \pm 0.02$ & $0.06 \pm 0.02^{*}$ & $0.06 \pm 0.02^{*}$ & $0.06 \pm 0.01 *$ \\
\hline CD34+/CD133+ & (\%PMBC) & $0.04 \pm 0.02$ & $0.04 \pm 0.02$ & $0.04 \pm 0.02$ & $0.04 \pm 0.01$ & $0.02 \pm 0.01$ & $0.03 \pm 0.01$ \\
\hline EPC-CFU & (per106 PBMC) & $45.8 \pm 12.5$ & $49.3 \pm 22$ & $28.2 \pm 6.4$ & $21.9 \pm 18.8$ & $14.5 \pm 21.3$ & $16.4 \pm 19.1$ \\
\hline estradiol & $(\mathrm{pmol} / \mathrm{l})$ & $188 \pm 79$ & $353 \pm 119$ & $664 \pm 138$ & $138 \pm 78$ & $285 \pm 150$ & $545 \pm 128$ \\
\hline progesterone & $(\mathrm{nmol} / \mathrm{l})$ & $2.6 \pm 0.6$ & $1.7 \pm 0.4$ & $55.3 \pm 26.9$ & $4.8 \pm 1.6$ & $2.8 \pm 0.8$ & $47.1 \pm 16.8$ \\
\hline
\end{tabular}

${ }^{*} p<0.05$ for comparison of non-smokers vs. smokers; values are mean \pm SD; CD34+ = progenitor cells positive for hematopoietic stem cell marker CD34; CD34+/CD133+ = progenitor cells positive for hematopoietic stem cell markers CD34 and CD133; EPC-CFU = endothelial progenitor cells analyzed in vitro by formation of colony forming units

to maintain endothelial function [20]. An imbalance of injury and repair of vasculature promotes the progression of atherosclerosis, and reduced PC levels may be a marker of such an imbalance caused by smoking [27].

PCs are known to be upregulated by estrogens through inhibition of apoptosis, stimulation of telomerase, and bone marrow mobilization $[11,28,29]$. Fertile women have higher levels of PCs than do age-matched men; after menopause, levels of PCs no longer evidence sex-specific differences [14]. Higher PC levels in fertile women have been suggested to contribute to the lower cardiovascular risk compared to men. In order to explain the effect of smoking and the estrogen status on progenitor cell and EPC-CFU content, we first examined women at menstruation, the cycle phase with lowest concentrations of sexual steroids. We established a significant decrease of CD34 + progenitor cells in smoking women. Importantly - in a cross-analysis of six different progenitor cell sub-

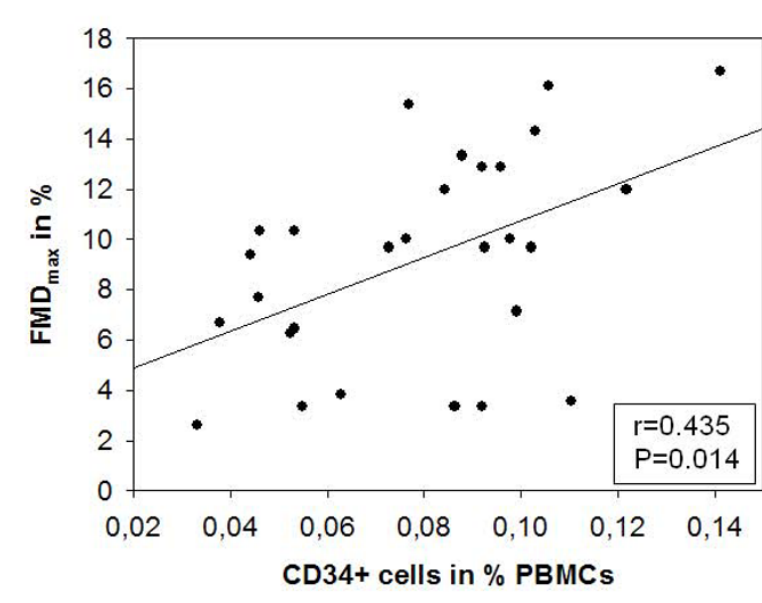

Figure 3 Relation between the number of circulating CD34 + progenitor cells and endothelial function. Measured as flow-mediated dilation (FMD) in the brachial artery in young healthy women. types characterized by different combinations of the surface markers CD34, CD133, and VEGFR2 - it had been previously shown that the abundance of the progenitor cell population with $\mathrm{CD} 34+$ alone revealed the best correlation with cardiovascular parameters and risk estimates [6]. Concordantly, we found a positive correlation of levels of CD34 + cells with endothelial function in young healthy women. These data concur with other studies describing a positive correlation between FMD and PCs: which emphasizes the close relationship of these two markers in reflection of vascular homeostasis $[6,14]$.

It is well established that cigarette smoking is sufficient to impair endothelial function in healthy adults $[18,30]$. Although hormonal cycle-dependent changes of endothelial function are relevant in premenopausal women, most clinical studies of the effects of smoking on endothelial-dependent vasodilation have not considered menstrual cycle phases in women. We have recently shown that there are no significant differences in endothelial function between smoking and non-smoking women at menstruation [31]. Consequently, the results of the present study support the conclusion that chronic smoking affects the level of CD34 + progenitor cells before manifestation of endothelial dysfunction in healthy young women. It has been suggested that oxidative stress and decreased availability of $\mathrm{NO}$ are causative for endothelial dysfunction induced by smoking $[32,33]$. Since there is evidence that NO is necessary for PC mobilization and function $[26,27,34]$, NO deficiency may be a key factor resulting in the PC decrease in young smoking women. We suggest, that deficient mobilization of PCs due to limited NO availability caused by smoking precedes detectable alterations of endothelial function and in this sense may represent a sensitive, early parameter of cardiovascular risk. Clearly, this should be an important consideration for future studies. 
Investigations of the influence of nicotine abuse on PC levels in premenopausal women should in fact consider hormonal fluctuations during the menstrual cycle. In our study, however, we found no significant differences in the amount of progenitor cells between follicular and luteal phases of the menstrual cycle, despite an increase in estrogen levels. These results concur with previous studies showing significant periovulatory increase of progenitor cells, but no differences between follicular and luteal phases [13-15]. It is interesting to note that the differences in levels of CD34 + cells between smoking and nonsmoking women were maintained in all three phases, independently of the estrogen status.

There are some limitations in the present study. In conjunction with the small sample size, smoking women were somewhat older than non-smoking. It cannot be ruled out that older age in smoking women contributes to decreased numbers of progenitor cells. However, adjustment of progenitor cell number and FMD values in a linear regression analysis did not show an influence of age differences on our study results.

\section{Conclusion}

The number of CD34 + progenitor cells positively correlates with FMD in young healthy women and is decreased by smoking.

\section{Competing interests}

The authors declare that they have no competing interests.

\section{Authors' contributions}

$\mathrm{AL}$ and NJ contributed to the concept and design of the study, data collection, analysis and interpretation of data, and drafting of the manuscript. AK, CK, SM contributed to data collection and analysis. CG performed the statistical analysis. GB, KS, VS contributed to the concept and design of the study, and critical review of the intellectual content of the manuscript. All authors read and approved the final manuscript.

\section{Acknowledgements}

We thank all volunteers who participated in the study. We are grateful for the excellent assistance of Susanne Metzkow.

\section{Author Details}

${ }^{1}$ Med. Klinik mit Schwerpunkt Kardiologie und Angiologie, Charité Universitaetsmedizin Berlin, Campus Mitte, Berlin, Germany and Institut für Biometrie und Klinische Epidemiologie, Charité - Universitaetsmedizin Berlin, Campus Mitte, Berlin, Germany

Received: 13 October 2009 Accepted: 30 May 2010

Published: 30 May 2010

\section{References}

1. Asahara T, Murohara T, Sullivan A, Silver M, van der Zee R, Li T, Witzenbichler B, Schatteman G, Isner JM: Isolation of putative progenitor endothelial cells for angiogenesis. Science 1997, 275:964-967.

2. Hill JM, Finkel T, Quyyumi AA: Endothelial progenitor cells and endothelial dysfunction. Vox Sang 2004, 2:31-37.

3. Huang PH, Chen YH, Chen YL, Wu TC, Chen JW, Lin SJ: Vascular endothelial function and circulating progenitor cells in patients with cardiac syndrome X. Heart 2007, 93:1064-1070.

4. Fadini GP, de Kreutzenberg SV, Coracina A, Baesso I, Agostini C, Tiengo A, Avogaro A: Circulating CD34 + cells, metabolic syndrome, and cardiovascular risk. Eur Heart J 2006, 27:2247-2255.
5. Müller-Ehmsen J, Braun D, Schneider T, Pfister R, Worm N, Wielckens K, Scheid C, Frommolt P, Flesch M: Decreased number of circulating progenitor cells in obesity: beneficial effects of weight reduction. Eur Heart J 2008, 29:1560-1568.

6. Hill JM, Zalos G, Halcox JP, Schenke WH, Waclawiw MA, Quyyumi AA Finkel T: Circulating endothelial progenitor cells, vascular function, and cardiovascular risk. N Engl J Med 2003, 348:593-600.

7. Vasa M, Fichtlscherer S, Aicher A, Adler K, Urbich C, Martin H, Zeiher AM, Dimmeler S: Number and migratory activity of circulating endothelial progenitor cells inversely correlate with risk factors for coronary artery disease. Circ Res 2001, 89:E1-7.

8. Wenger NK: Coronary heart disease: an older woman's major health risk. BMJ 1997, 315:1085-1090.

9. Mendelssohn ME, Karas RH: The protective effects of estrogen on the cardiovascular system. N Engl J Med 1999, 340:1801-1811.

10. Cignarella A, Paoletti R, Puglisi L: Direct effects of estrogen on the vessel wall. Med Res Rev 2001, 21:171-184.

11. Strehlow K, Werner N, Berweiler J, Link A, Dirnagl U, Priller J, Laufs K, Ghaeni L, Milosevic M, Böhm M, Nickening G: Estrogen increases bone marrow-derived endothelial progenitor cell production and diminishes neointima formation. Circulation 2003, 107:3059-3065.

12. Iwakura A, Luedemann C, Shastry S, Hanley A, Kearney M, Aikawa R, Isner $J M$, Asahara T, Losordo DW: Estrogen-mediated, endothelial nitric oxide synthase-dependent mobilization of bone marrow-derived endothelial progenitor cells contributes to reendothelialization after arterial injury. Circulation 2003, 108:3115-3121.

13. Masuda H, Kalka C, Takahashi T, Yoshida M, Wada M, Kobori M, Itoh R, Iwaguro H, Eguchi M, Iwami Y, Tanaka R, Nakagawa Y, Sugimoto A, Ninomiva S, Hayashi S, Kato S, Asahara T: Estrogen-mediated endothelial progenitor cell biology and kinetics for physiological postnatal vasculogenesis. Circ Res 2007, 101:598-606.

14. Fadini GP, de Kreutzenberg S, Albiero M, Coracina A, Pagnin E, Baesso I, Cignarella A, Bolego C, Plebani M, Nardelli GB, Sartore S, Agostini C, Avogaro A: Gender differences in endothelial progenitor cells and cardiovascular risk profile: the role of female estrogens. Arterioscler Thromb Vasc Biol 2008, 28:997-1004.

15. Lemieux C, Cloutier I, Tanguay JF: Menstrual cycle influences endothelial progenitor cell regulation: A link to gender differences in vascular protection? Int J Cardiol 2009, 136:200-210.

16. Khot UN, Khot MB, Bajzer CT, Sapp SK, Ohman EM, Brener SJ, Ellis SG Lincoff AM, Topol EJ: Prevalence of conventional risk factors in patients with coronary heart disease. JAMA 2003, 290:898-904.

17. Mayhan WG, Scarpe GM: Effect of cigarette smoke extract on arteriolar dilatation in vivo. J Appl Physiol 1996, 81:1996-2003.

18. Neunteufl T, Heher S, Kostner K, Mitulovic G, Lehr S, Khoschsorur G, Schmid RW, Maurer G, Stefenelli T: Contribution of nicotine to acute endothelial dysfunction in long-term smokers. J Am Coll Cardiol 2002, 39:251-256.

19. Yanbaeva DG, Dentener MA, Creutzberg EC, Wesseling G, Wouters EFM: Systemic effects of smoking. Chest 2007, 131:1557-1566.

20. Kondo T, Hayashi M, Takeshita K, Numaguchi Y, Kobayashi K, lino S, Inden $Y$, Murohara T: Smoking cessation rapidely increases circulating progenitor cells in peripheral blood in chronic smokers. Arterioscler Thromb Vasc Biol 2004, 24:1442-1447.

21. Lorenz M, Jochmann N, von Krosigk A, Martus P, Baumann G, Stangl K, Stangl V: Addition of milk prevents vascular protective effects of tea. Eur Heart J 2007, 2:219-223.

22. Corretti MC, Anderson TJ, Benjamin EJ: Guidelines for the ultrasound assessment of endothelial-dependent flow-mediated vasodilation of the brachial artery: a report of the International Brachial Artery Reactivity Task Force. J Am Coll Cardiol 2002, 39:257-265.

23. Pyke KE, Tschakovsky ME: The relationship between shear stress and flow-mediated dilation: implications for the assessment of endothelial function. J Physiol 2005, 568:357-369.

24. Willett CG, Boucher Y, di Tomaso E, Duda DG, Munn LL, Tong RT, Chung DC, Sahani DV, Kalva SP, Kozin SV, Mino M, Cohen KS, Scadden DT, Hartford AC, Fischman AJ, Clark JW, Ryan DP, Zhu AX, Blaszkowsky LS, Chen HX, Shellito PC, Lauwers GY, Jain RK: Direct evidence that the VEGFspecific antibody bevacizumab has antivascular effects in human rectal cancer. Nat Med 2004, 10:145-147.

25. Boilson BA, Kiernan TJ, Harbuzariu A, Nelson RE, Lerman A, Simari RD: Circulating CD34 + cell subsets in patients with coronary endothelial dysfunction. Nat Clin Pract Cardiovasc Med 2008, 8:489-496. 
26. Heeschen C, Aicher A, Lehmann R, Fichtlscherer S, Vasa M, Urbich C, Mildner-Rihm C, Martin H, Zeiher AM, Dimmeler S: Essential role of endothelial nitric oxide synthase for mobilization of stem and progenitor cells. Nat Med 2003, 108:2511-2516.

27. Umemura T, Higashi Y: Endothelial progenitor cells: therapeutic target for cardiovascular diseases. J Pharmacol Sci 2000, 108:1-6.

28. Aicher A, Zeiher AM, Dimmeler S: Mobilizing endothelial progenitor cells. Hypertension 2005, 45:321-325

29. Imanishi T, Hano T, Nishio I: Estrogen reduces endothelial progenitor cell senescene through augmentation of telomerase acitvity. J Hypertens 2005, 23:1699-1706.

30. Celermajer DS, Sorensen KE, Georgakopoulos D, Bull C, Thomas O, Robinson J, Deanfield JE: Cigarette smoking is associated with doserelated and potentially reversible impairment of endothelialdependent dilation in healthy young adults. Circulation 1993, 88:2149-2155.

31. Jochmann N, Mueller S, Kuhn C, Gericke C, Baumann G, Stangl K, Stangl V: Chronic smoking prevents amelioration of endothelial function in the course of the menstrual cycle. Circ J 2009, 73:568-572.

32. Raij L, DeMaster EG, Jaimes EA: Cigarette smoke-induced endothelium dysfunction: role of superoxide anion. J Hypertens 2001, 19:891-897.

33. Tsuchiya M, Asada A, Kasahara E, Sato EF, Shindo M, Inoue M: Smoking a single cigarette rapidly reduces combined concentrations of nitrate and nitrite and concentrations of antioxidants in plasma, Circulation. 2002, 105:1155-1157.

34. Michaud SE, Dussault S, Haddad P, Groleau J, Rivard A: Circulating endothelial progenitor cells from healthy smokers exhibit impaired functional activities. Atherosclerosis 2006, 187:423-432.

\section{Pre-publication history}

The pre-publication history for this paper can be accessed here: http://www.biomedcentral.com/1472-6874/10/20/prepub

doi: $10.1186 / 1472-6874-10-20$

Cite this article as: Ludwig et al., Smoking decreases the level of circulating CD34+ progenitor cells in young healthy women - a pilot study BMC Women's Health 2010, 10:20

Submit your next manuscript to BioMed Centra and take full advantage of:

- Convenient online submission

- Thorough peer review

- No space constraints or color figure charges

- Immediate publication on acceptance

- Inclusion in PubMed, CAS, Scopus and Google Scholar

- Research which is freely available for redistribution

Submit your manuscript at www.biomedcentral.com/submit
C Biomed Central 